\title{
SWOT analysis for an environment friendly urban transport system
}

\author{
A. G. Öncel \\ Department of Business Administration, Galatasaray University, Turkey
}

\begin{abstract}
Urban transport has become a more significant source of the pollution of environment. The environmental problems have two aspects: local and global. Local environmental problems include air pollution and noise. As for instance, diesel engines are significant contributors to air pollution. Some of the basic types of exhaust have a strong obnoxious impact on live organisms. They include cancer-causing substances and also contain other harmful pollutants. Even if allelectric suburb railway transport does not have effect on air pollution, they are the source of noise pollution. From the point of view of a global environmental problem, a great part of total greenhouse gas emissions are mainly caused by urban transport, especially road transport. At this point, environment friendly urban transport systems have a crucial role in saving environmental quality.

In our study, we start by presenting the main local and global environmental problems caused by urban transport. Our study focuses on İstanbul urban transport systems from environmental point of view. We present basic data about İstanbul's transport system and transport policy. This study uses a SWOT analysis to study İstanbul transport system from the environmental point of view. We analyze strengths, weaknesses, opportunities, and threats of the system and put forward recommendations. Finally our paper summarizes the experiences from İstanbul.
\end{abstract}

Keywords: urban transportation, SWOT analysis, greenhouse effect, environment.

\section{Introduction}

Climate change is one of the greatest threats facing the planet. The atmosphere contains vapor, carbon dioxide and other naturally occurring gases that let in 
sunlight but absorb the heat that is radiated back off the Earth (see e.g. [1]). This natural process, called the "greenhouse effect" keeps the Earth's temperature at a level that supports life.

Some greenhouse gases, such as carbon dioxide, occur naturally and are emitted to the atmosphere through natural processes and human activities. Other greenhouse gases are created and emitted solely through human activities. The principal greenhouse gases that are emitted to the atmosphere as a result of human activities are:

Carbon Dioxide $\left(\mathrm{CO}_{2}\right)$ : Carbon dioxide is emitted via the burning of fossil fuels like oil, natural gas, and coal, solid waste, trees and wood products, and also as a result of other chemical reactions. Carbon dioxide is also removed from the atmosphere when it is absorbed by plants as part of the biological carbon cycle. Hence, the devastation of forests prevents the absorption of carbon dioxide.

Methane $\left(\mathrm{CH}_{4}\right)$ : Methane is emitted during the production and transport of coal, natural gas, and oil.

Nitrous Oxide $\left(\mathrm{N}_{2} \mathrm{O}\right)$ : Nitrous oxide is emitted during agricultural and industrial activities, as well as during combustion of fossil fuels and solid waste.

Fluorinated Gases: They are synthetic, powerful greenhouse gases that are emitted from a variety of industrial processes

However, a human activity such as burning of fossil fuels is increasing the levels of carbon dioxide and other heat-trapping gases in the atmosphere. At this point, sustainable transport system plays a great role (Ülengin et al. [2], Hensher [3]). An environmentally sustainable transport system can be defined as "one where transportation does not endanger public health or ecosystems and meets needs for access consistent with use of renewable resources below their rates of regeneration and use of non-renewable resources below the rates of development of renewable substitutes (Browne et al. [4])."

\section{Environmental problems caused by urban transport}

The environmental problems have two aspects: local and global. Local environmental problems include air pollution and noise [5]. Diesel engines are significant contributors to air pollution. Diesel exhaust is produced when an engine burns diesel fuel. Some of basic types of exhaust have strong poisonous impact on live organism. They include cancer-causing substances and also contain other harmful pollutants. Whether all-electric suburb railway transport does not have effect on air pollution, they are the source of noise pollution. From the point of view of global environmental problem, a great part of total greenhouse gas emissions are mainly caused by urban transport, especially road transport (Kamble et al. [6], Barros and Dieke [7]). At this point, environment friendly urban transport systems have a crucial role in saving improving environmental quality. 
The atmosphere contains vapour, carbon dioxide and other naturally occurring gases that let in sunlight but absorb the heat that is radiated back off the Earth. This natural process is the greenhouse effect. It keeps the Earth's temperature at a level that supports life. The burning of fossil fuels and the destruction of forests are increasing the levels of carbon dioxide and other heattrapping gases in the atmosphere. Fossil fuels for transport are major sources of greenhouse gas emissions [1]. These greenhouse gases enhance the natural greenhouse effect which makes the Earth warmer and changes the climate.

Table 1: $\quad$ Greenhouse gas emissions from different transport modes [8].

\begin{tabular}{|l|c|c|c|c|}
\hline \multicolumn{1}{|c|}{ Mode } & $\begin{array}{c}\mathrm{CO}_{2} \text {-equivalent } \\
\text { emissions } \\
\text { (grams /vehicle- } \\
\mathrm{km} \text { ) }\end{array}$ & $\begin{array}{c}\text { Maximum } \\
\text { capacity } \\
\text { (passengers) }\end{array}$ & $\begin{array}{c}\text { Average } \\
\text { capacity } \\
\text { (passengers) }\end{array}$ & $\begin{array}{c}\mathrm{CO}_{2} \text {-equivalent } \\
\text { emissions (grams } \\
\text { /passenger-km) }\end{array}$ \\
\hline Pedestrian & 0 & 1 & 1 & 0 \\
\hline Bicycle & 0 & 2 & 1.1 & 0 \\
\hline $\begin{array}{l}\text { Gasoline motor scooter } \\
\text { (2-stroke) }\end{array}$ & 118 & 2 & 1.2 & 98 \\
\hline $\begin{array}{l}\text { Gasoline motor scooter } \\
\text { (4-stroke) }\end{array}$ & 70 & 2 & 1.2 & 64 \\
\hline Gasoline car & 293 & 5 & 1.2 & 244 \\
\hline Gasoline taxi car & 293 & 5 & 0.5 & 586 \\
\hline Diesel car & 172 & 1.2 & 1.2 & 143 \\
\hline Diesel minibus & 750 & 20 & 15 & 50 \\
\hline Diesel bus & 963 & 80 & 65 & 15 \\
\hline $\begin{array}{l}\text { Compressed natural gas } \\
\text { bus }\end{array}$ & 1050 & 80 & 65 & 16 \\
\hline Diesel articulated bus & 1000 & 160 & 130 & 7 \\
\hline
\end{tabular}

\section{Turkey urban transport modes and environmental effects}

In developed countries, transportation statistics indicate that there is an increase in road transportation for passengers and goods (Öncel and Ersoy [9]). Road transportation is generally preferred to the other modes of transportation since it provides rapid and continuous move of products from the production point to the end users. In Turkey, the percentage use of road transportation in overall transportation modes is higher than that of the World average. This fact causes a lot of accidents, congestion and pollution, and limits the mobility for economic development. In European countries, new projects on maritime transportation are supported in order to diminish the part of the road transportation [5].

During the early periods of the Turkish Republic from 1923 to the 1950 s, governments supported the rail and maritime transportations which were the correct choices for both passengers and goods [10]. As a result of the big progress performed during the first two decades of the Turkish Republic, many 
big cities and industrial zones of the counties have been connected via railroad network. According to a statistical survey made during this era, it has been observed that $55.1 \%$ of the freight was carried by rail, $27.8 \%$ of it was transported by maritime lines and the rest (17.1\%) was shipped by road transport. Afterwards, a stagnation period for rail transportation began. Moreover, the maritime transportation sector, which consists of ship construction companies, maritime companies and dock service organizations, was only managed by the government. Road transportation accelerated its progress, as a result of the start of economic assistance of the Marshall Plan in 1948 and the foundation of the Turkish General Directorate of Highways. However, the same acceleration has not been observed for the other transportation modes.

After the 1950s, all governments pursued policies to support road transportation which is known to be one of the most expensive transportation modes. Hence, today the transportation of Turkey depends on the roadway to a large extent. Consequently, more than $90 \%$ of the total passenger and freight transportation is carried out by roadways. This is clearly a very costly and imbalanced transportation system. During the last decades this imbalance has worsened in spite of many decision makers who are aware of this problem. Furthermore, the fact that the percentage of maritime transportation investments is $2.4 \%$ of the total transportation investments shows clearly the imbalance of the transportation policy.

The higher usage of road transportation yields an increase of greenhouse gas emissions. The total greenhouse gas emission increase from 2000 to 2006 is given with table 2 (see [11]).

Table 2: Greenhouse gas emissions (million tones $\mathrm{CO}_{2}$ eq.) from 2000 to 2006 in Turkey.

\begin{tabular}{|l|r|r|r|r|r|r|r|}
\hline & 2000 & 2001 & 2002 & 2003 & 2004 & 2005 & 2006 \\
\hline $\mathrm{CO}_{2}$ & 223.80 & 207.38 & 216.43 & 230.99 & 241.88 & 256.43 & 273.70 \\
\hline $\mathrm{CH}_{4}$ & 49.27 & $48 ., 70$ & 46.87 & 47.76 & 46.29 & 49.32 & 50.33 \\
\hline $\mathrm{N}_{2} \mathrm{O}$ & 5.74 & 4.84 & 5.41 & 5.25 & 5.49 & 3.43 & 4.59 \\
\hline $\mathrm{F}$ & 1.14 & 1.18 & 1.90 & 2.29 & 2.93 & 3.24 & 3.13 \\
\hline Total & 280.0 & 262.1 & 270.6 & 286.3 & 296.6 & 312.4 & 331.8 \\
\hline
\end{tabular}

Similarly, considering the data collected from the energy sector, it has been estimated that total greenhouse gas emission was 331.0 million tones during 2006 and $78 \%$ of this emission produced from the energy sector. Compared with 2000 , emission produced from the energy sector has increase $21.48 \%$.

When we look at the final energy consumption by the transport sector, there is an increase of $18.25 \%$ in transport since 1996 [12]. In the case of the final consumption by mode of transport, we see a significant gap between road and rail transport. The final consumption by road transport increased in Turkey, which showed a growth of $14.3 \%$ since 1996 . This one preserved its high share of $83.21 \%$ in total transport consumption in 2006 . In contrast with road transport, 
rail transport has shown a 7.14\% decline since 1996. In 2006, rail transport represented only $1.83 \%$ of total transport consumption.

Environment indicators about emissions of greenhouse gases show that in Turkey there has been a significant increase of 95.25\% from 1990 to 2006 [13]. Figure 1 illustrates the trend in transport greenhouse gas emissions by European countries from 1990 to 2005 which indicates that Turkey has a considerably high greenhouse gas emission.

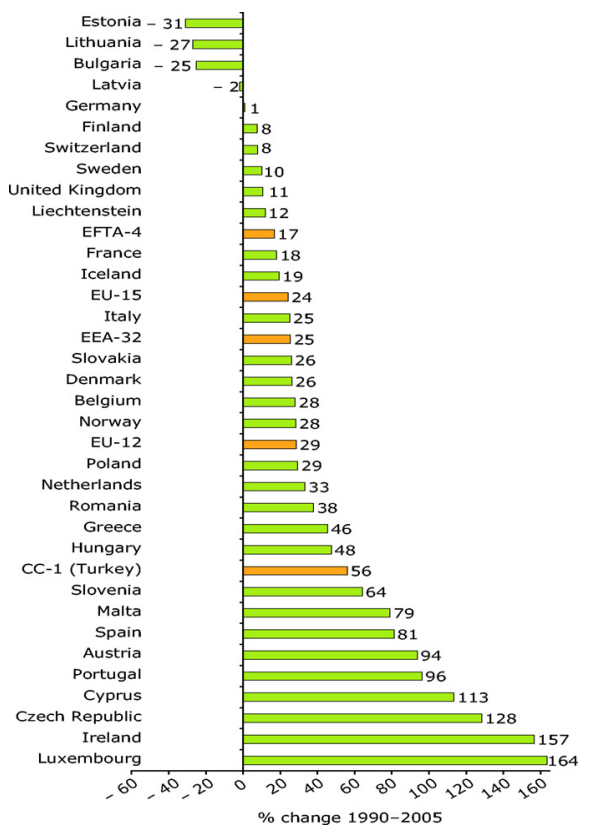

Figure 1: $\quad$ Percent changes in greenhouse gas emissions from 1990 to 2005.

\section{4 İstanbul Urban Transport Policy}

The intra-city transportation system of İstanbul consists of roadway, maritime and railway transportations. Among these, road transportation has the highest percentage. Table 3 shows the percentage of transport modes in İstanbul in 1996 and 2006 (Gerçek [14]). It can be observed that the percentage of road transportation is increased while the percentage of maritime transportation has decreased despite it is the most harmless transportation mode.

Figure 2 illustrates the increase in the number of motor vehicles in Turkey and in İstanbul from 2001 to 2007 [11]. It can be seen that the use of road transportation mode has a considerable share in Turkey. Figure 3 particularly illustrates that among all road motor vehicles, automobiles has the greatest percentage. In other words automobile has the greatest responsibility in the total greenhouse gas emission in İstanbul. 
Table 3: $\quad$ Percentage of transport modes in İstanbul.

\begin{tabular}{|l|r|r|}
\hline Transport Mode in İstanbul & 1996 & 2006 \\
\hline Car & 19.3 & 26.3 \\
\hline Taxi + Dolmuş & 9.4 & 4.8 \\
\hline Company/School Buses & 11.4 & 21.5 \\
\hline Bus & 34.1 & 24.1 \\
\hline Minibus & 19.6 & 16.7 \\
\hline Rail & 3.6 & 4.6 \\
\hline Sea & 2.6 & 2 \\
\hline Total & 100 & 100 \\
\hline
\end{tabular}

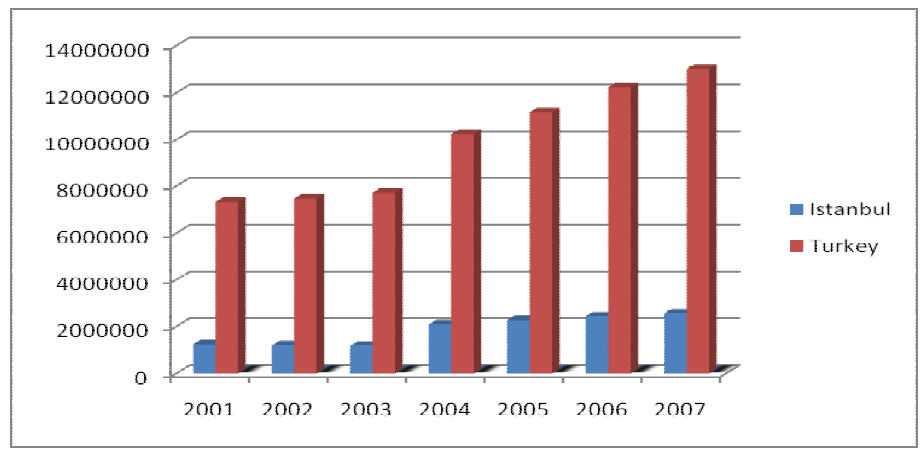

Figure 2: Increase in the number of motor vehicles in Turkey and in İstanbul from 2001 to 2007.

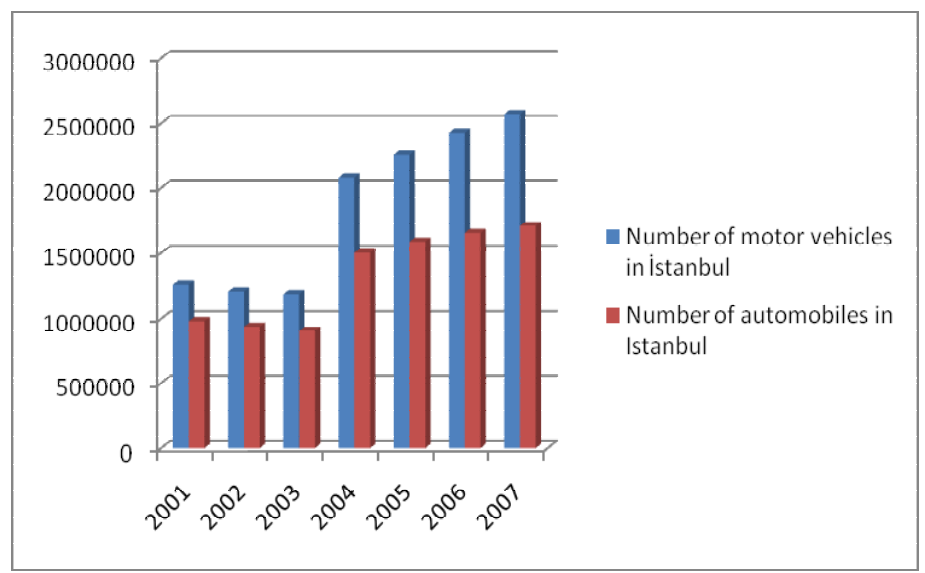

Figure 3: Number of motor vehicles and automobiles in İstanbul from 2001 to 2007 . 
Considering the percentage of road motor vehicles by kind of fuel used (see figure 4) there exists a continuous increase in diesel motor vehicles since 2001 [11]. Diesel engines are significant contributors to air pollution. Diesel exhaust has strong a obnoxious impact on live organisms. They include cancer-causing substances and also contain other harmful pollutants.

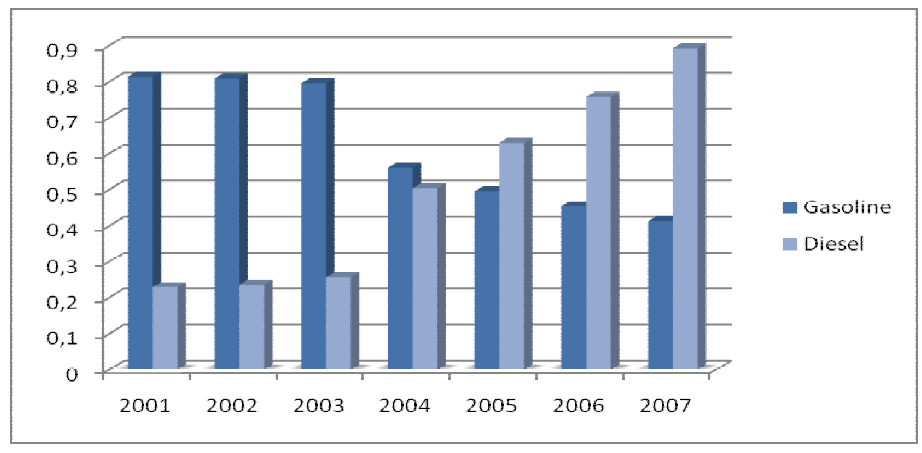

Figure 4: Percentage of road motor vehicles by kind of fuel used between the years 2001 and 2007, in Turkey

\section{SWOT analysis for İstanbul urban transport}

SWOT (strengths, weaknesses, opportunities and threats) analysis is one of the most effective tools to assess the strategic situation and helps to identify strategic options for organizations. Strength is a resource that the organization can use effectively to achieve its objectives. A weakness is a limitation, fault or defect in the organization that will keep it from achieving its objectives. An opportunity is any favorable situation in the organization's environment and a threat is any unfavorable situation in the organization's environment that is potentially damaging to its strategy (Rowe et al. [15]). In this study, we use to analyze the characteristics of İstanbul urban transport system from the environmental aspect.

\section{Strengths:}

- Railway transportation projects have gained increased importance during the last few years. This has positive impact on reducing the hazardous effect of road transportation on the environment.

- In İstanbul, maritime transportation is also used for many years for crossing the Bosphorus strait.

- Nonprofit organizations are more sensitive to environmental issues. They are working for making people conscious of this topic.

- The Kyoto protocol has been signed by Turkish government. Weaknesses:

- Transportation system mainly consists of road transportation mode.

- Due to wide traffic congestions in İstanbul hazardous emissions is very high. 


\section{Opportunities:}

- It is possible to cooperate with other countries which have signed Kyoto Protocol and to benefit from their experiences. This will help to coordinate of attempts to control the greenhouse gas emission.

\section{Threats:}

- The population of İstanbul rapidly increases every year.

- People are not enough aware of the problem.

- With the low credit rates, more and more vehicles are sold and driven on the roads.

\section{What must be done:}

- To reduce the number of old vehicles.

- To encourage walking and cycling as viable alternatives to private vehicles.

- To increase the research budgets for environment friendly vehicles. Among environment friendly vehicles, the ones that consume bio-fuel are widely used. Bio-fuels are the main substitute for petrol and diesel in transport available on a large scale and usable in ordinary vehicles. The use of bio-fuels, such as bio-fuels, bio-ethanol and bio-gas can therefore be an important way of promoting more sustainable energy use in transport and of reducing dependence on fossil fuels.

- The provision of good quality, environmentally-friendly collective transport

- The adjustment of tax rates according the fuel consumptions of the vehicles.

- Several alternative biological materials can be used as substitute of petrol. The most important ones are vegetable oils, cereals and organic waste material. Vegetable oils (e.g. rapeseed oil, soya oil, sunflower seed) can be transformed into materials which can replace diesel. Cereals, such as sugar beer, can be fermented to obtain bio-ethanol which can be consumed as a substitute of fuels. Organic waste materials such as animal, plant and human waste, can be transformed into biofuels.

\section{Conclusion}

Road transportation in big cities is one of the main causes of the greenhouse gas emission which yield global climate change. Especially the diesel fuel used in motor vehicles is the reason for environmental pollution. In this work we have considered different transportation modes in İstanbul and a SWOT analysis for Istanbul urban transport system is presented. Several solutions for this problem and a comparative discussion have been presented. 


\section{Acknowledgements}

The author thanks to Dr. Temel Öncan for his contribution to the presentation of this paper. The author also acknowledges the support by Galatasaray University Research Foundation.

\section{References}

[1] "Combating climate change-The EU leads the way", Europe on the move series. Publication of European Commission, September 2007

[2] Ülengin, F., Kabak, Ö., Önsel, Ş., Ülengin, B. \& Aktaş, E. “A problemstructuring model for analyzing transportation-environment relationships", European Journal of Operational Research (2009), doi: 10.1016/j.ejor.2009.01.023.

[3] Hensher, D.A., "Climate change, enhanced greenhouse gas emissions and passenger transport-What can we do make a difference?", Journal of Transportation Research Part D, 13, 95-111, 2008.

[4] Browne, D., O'Regan, B. \& Moles, R., "Use of ecological footprinting to explore alternative transport policy scenarios in an Irish city-region" Journal of Transportation Research Part D, 13, pp. 315-322, 2008.

[5] Organization for Economic Cooperation and Development (OECD) Report, 2004. Environmentally Sustainable Transport, 2004, Paris.

[6] Kamble, S.H., Mathew, T.V. \& Sharma, G.K., "Development of realworld driving cycle: Case study of Pune, India", Journal of Transportation Research Part D, 14, 132-140, 2009.

[7] Barros, C.P. \& Dieke, P.U.C., "Choice valuation of traffic restrictions: Noise, pollution, and congestion preferences. A note" Journal of Transportation Research Part D, 13, 347-350, 2008.

[8] www.worldbank.org/annualreport/2003/ World Bank report June 2003.

[9] Öncel, A.G. \& Ersoy, M.Ș. "Evaluation of Bosphorus crossing alternatives by topsis method" Proceedings of the 3rd International Logistics and Supply Chain Congress, 347-354, Istanbul, Turkey, 23-24 November 2005 LCDM, 2005.

[10] Ulaştırma Ana Planı Stratejisi, Sonuç Raporu, Turkish General Directorate of Highways, 2004.

[11] www.tuik.gov.tr

[12] http://epp.eurostat.ec.europa.eu

[13] AB Komisyonu (2001), "White Paper, European Transport Policy for 2010: Time to Decide"

[14] H. Gerçek, "Round Table "National experiences in control of the energy on the sector of building» Event Energaia, December 10-12,2008

[15] Rowe, A.J., Mason, R.O., Dickel, K.E., Mann, R.EB \& Mockler, R.J. Strategic Management: A Methodological Approach, $4^{\text {th }}$ Edition, Addison-Wesley. Reading Massachusetts, 1994. 